\title{
Effects of tillage, fallow and burning on selected properties and fertility status of Andosols in the Mounts Bambouto, West Cameroon
}

\author{
Paul Tematio $^{1^{*}}$, Ertine Isabelle Tsafack ${ }^{2}$, Lucas Kengni ${ }^{2}$ \\ ${ }^{1}$ Department of Earth Science, University of Dschang, Dschang, Cameroon; *Corresponding Author: paultematio@yahoo.fr \\ ${ }^{2}$ Department of Earth Science, University of Dschang, Dschang, Cameroon.
}

Received 28 January 2011; revised 23 May 2011; accepted 7 July 2011.

\begin{abstract}
To assess the impact of land use on the Andosol fertility, changes in chemical and physical properties affecting soil quality were monitored on Andosols from Mount Bambouto submitted to four different land uses and management systems: natural cover, tillage, burning and fallow. In comparison with the natural cover, tillage reduces Andosol OC (6.5\% to $4.8 \%)$, total $\mathrm{N}$ (4.51\%o to $2.95 \%$ ), CEC (22.0 to $20.9 \mathrm{cmol} \cdot \mathrm{kg}^{-1}$ ) and the abundance of soil macro-aggregates expressed by the water stable aggregates (WSA) varies from $53.8 \%$ to $12.0 \%$; and increases the bulk density $\left(0.69\right.$ to $\left.1.09 \mathrm{~g} \cdot \mathrm{cm}^{-3}\right)$ and the sum of exchangeable cations ( 3.58 to $\left.4.84 \mathrm{cmol} \cdot \mathrm{kg}^{-1}\right)$. Burning also reduces Andosol OC (6.5\% to $0.8 \%)$, total $N(4.51 \%$ to $0.95 \%)$ and CEC $(22.0$ to $\left.10.2 \mathrm{cmol} \cdot \mathrm{kg}^{-1}\right)$, but increases soil $\mathrm{pH}(4.62$ to 6.54), the sum of exchangeable cations ( 3.58 to $5.74 \mathrm{cmol} \cdot \mathrm{kg}^{-1}$ ) and the abundance of soil macro-aggregates (WSA: $38.2 \%$ to $57.0 \%$ ). In comparison with tillage, fallow increases Andosol OC $(4.8 \%$ to $6.5 \%)$, total $N(2.95 \%$ to $5.04 \%$ ), CEC (18.0 to $21.6 \mathrm{cmol} \cdot \mathrm{kg}^{-1}$ ), the sum of exchangeable cations ( 3.58 to $5.05 \mathrm{cmol} \cdot \mathrm{kg}^{-1}$ ) and the abundance of soil macro-aggregates (WSA: $12.0 \%$ to $48.8 \%$ ). Globally, the tillage management deteriorates Andosol chemical and physical properties affecting fertility, whereas the fallow management restores them. The burning management also improves some Andosol chemical and physical properties affecting quality, but it won't last long.
\end{abstract}

Keywords: Andosols; Land Use Management Systems; Soil Physic-Chemical Properties; Soil Fertility

\section{INTRODUCTION}

Soil quality is fundamental for sustainable agriculture development [1]. The land use and management systems strongly influence soil quality expressed by changes in soil chemical and physical properties (organic matter content, CEC, sum of exchangeable cations, acidity, bulk density, aggregates stability, etc.). Thus, improper land use and management systems reduce soil fertility and the subsequent food security [2]. Many studies on soil fertility have focused mainly on nutrients budget and balances $[3,4]$ without emphasis on changes in soil chemical and physical properties affecting soil quality over time.

In Mount Bambouto, a volcanic mountain of the West Cameroon Highlands where Andosols are widespread [5] (Figure 1), strong human pressures on lands expressed by the tillage and burning management systems have affected the agro-ecosystems over the past 30 years [6]. One of the consequences is the overexploitation of soil resources with subsequent crop yields decrease. Considering the precarious conditions of Andosols characterized by a rapid degradation of the majority of their chemical and physical properties when farming, new strategies for sustainable management of Andosols in this area have to be found urgently. Therefore, it might be useful to identify the land use and management systems impacts on Andosol fertility in Mount Bambouto. The main objective of this study is to quantify changes in chemical and physical properties of the Andosols from Mount Bambouto submitted to tillage, burning or fallow management systems in order to compare the effects of these land uses and management systems on Andosol quality changes. This would contribute to propose standard systems that safeguard Andosol quality.

\section{MATERIALS AND METHODS}

This study was carried out in Mount Bambouto, one 


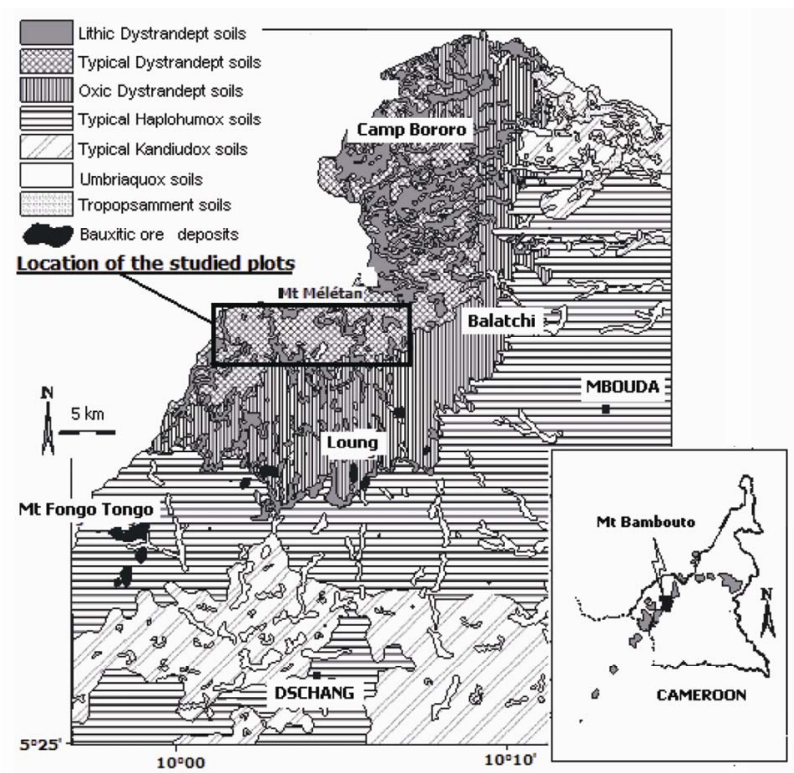

Figure 1. Location of the studied plots in the soil distribution map of Mount Bambouto (after Tematio et al., 2004).

of the major volcanoes in the Cameroon Volcanic Line that crosses the western part of the Cameroon territory. In this mountain, a recent soils survey [5] points out that Andosols are widespread above the altitude $2000 \mathrm{~m}$ (Figure 1).

They are shallow weathered pedons, either with A and $\mathrm{BC}$ horizons when developed on crests and steep slopes, or A, B and BC horizons when developed on foot-slopes. The surface horizon A is the main agricultural soil horizon supporting crops farming. It corresponds to a thick (up to $60 \mathrm{~cm}$ ) and dark grey to dark brown (10YR3/2 10YR3/3) loamy soil with fine to coarse crumbly structure. These Andosols in Mount Bambouto are mainly devoted to Irish potato and cabbage farming.

In this area, 17 plots were selected with respect to the farming crops (Irish potatoes), the slopes gradient (slightly undulated landscape), the landscape position (foot-slopes), the type of land use and management system applied and its duration. They are distributed as follow: 3 plots under the natural cover named NT, 2 plots under the short-term (5 years) tillage (T1), 4 plots under the long-term (10 years) tillage (T2), 2 plots under the short-term ( 5 years) burning (B1), 2 plots under the long-term (10 years) burning (B2), 2 plots under the short-term (5 years) fallow (F1) and 2 plots under the long-term (10 years) fallow (F2). In this area, the most significant variations in chemical and physical properties induced by the different land use and management systems occurred within the first $40 \mathrm{~cm}$ of the surface horizon A. That is why in each selected plot, soil samples for chemical analyses were collected at $20 \mathrm{~cm}$ depth, mixed, air dried, crushed and 2 $\mathrm{mm}$ sieved. Undisturbed soil samples were also collected at the same depth for bulk density and aggregates stability measurements.

Chemical analyses include the soil organic carbon $(\mathrm{OC})$, the total nitrogen $(\mathrm{N})$, the available phosphorus (P), the exchangeable cations; the cations exchange capacity (CEC) and the soil $\mathrm{pH}$. OC was extracted by oxidation with potassium dichromate in strongly acid solution and determined using a TOC-5000A analyzer. The total $\mathrm{N}$ was determined by Kjeldahl method, the available $\mathrm{P}$ by Bray II method and the exchangeable cations extracted by $\mathrm{NH}_{4} \mathrm{OAc}$ buffered at $\mathrm{pH} 7$ and determined by atomic absorption spectrophotometer. The $\mathrm{CEC}$ at $\mathrm{pH}$ 7 was determined using ammonium acetate method. The soil $\mathrm{pH}$ was determined in a 1:2.5 soil suspension with deionised water.

Physical analyses refer to the bulk density (da), the particle size distribution and the soil aggregate stability. da was obtained using the cylinder of Koppeki method [7]. With regard to the particle size distribution, sand fraction was separated by wet-sieving with $63 \mu \mathrm{m}$ sieve, oven dried at $105^{\circ} \mathrm{C}$ and weighed. Silts and clay fractions were determined by laser diffraction after destruction of organic matter with hydrogen peroxide, followed by the particle dispersal in sodium hexametaphosphate solution. The soil aggregate stability was determined according to Le Bissonnais method [8] which combines 3 disruptive tests: slow wetting, fast wetting and mechanical breakdown by shaking after pre-wetting tests. After each test, residual aggregates were collected and sieved using a column of six sieves: 2000, 1000, 500, 200,100 , and $50 \mu \mathrm{m}$. The proportion of each fraction size of stable aggregates was calculated.

Data analyses refer to the sum of exchangeable cations $(\mathrm{S})$, the cations equilibrium $(\mathrm{Ca} / \mathrm{Mg} / \mathrm{K}), \mathrm{Al}^{3+}$ toxicity $(\mathrm{m})$ and the soil aggregate stability calculation. $\mathrm{S}$ is obtained by summing up the exchangeable cations. The cations equilibrium noted $(\mathrm{Ca} / \mathrm{Mg} / \mathrm{K})$ is the relative abundance of $\mathrm{Ca}^{2+}, \mathrm{Mg}^{2+}$ and $\mathrm{K}^{+}$in soil qualifying the competition between the above cations during plant nutrition.

$$
m=\frac{\mathrm{Al}^{3+}}{\left(\mathrm{Al}^{3+}+s\right)} .
$$

represents the concentration of free $\mathrm{Al}^{3+}$ in the soil solution. The soil aggregate stability is expressed by the water stable aggregates (WSA), the geometric mean diameter $(G M D)$ and the mean weight diameter (MWD) of the soil aggregates above $0.5 \mathrm{~mm}$ size. They correspond to:

$$
\begin{gathered}
W S A=\frac{\sum_{i=1}^{n} w_{i} x_{i}}{w_{0}} . \\
G M D=\exp \frac{\sum_{i=1}^{n} w_{i} \log x_{i}}{\sum_{i=1}^{n} w_{i}} .
\end{gathered}
$$


Table 1. Mean values of the physical and chemical soil characteristics in the study plots.

\begin{tabular}{|c|c|c|c|c|c|c|c|c|c|c|c|c|c|c|c|c|c|c|}
\hline \multirow{2}{*}{\multicolumn{2}{|c|}{$\begin{array}{l}\text { Study } \\
\text { plots }\end{array}$}} & \multicolumn{3}{|c|}{ Soil organic matter } & \multicolumn{5}{|c|}{ Exchangeable cations } & \multirow{2}{*}{$\mathrm{CEC}-$} & \multicolumn{2}{|c|}{$\begin{array}{l}\text { Exchange- } \\
\text { able acidity }\end{array}$} & $\begin{array}{c}\text { Soil } \\
\text { acidity }\end{array}$ & \multirow{2}{*}{$\begin{array}{c}\text { Bulk } \\
\text { density } \\
\left(\mathrm{g} \cdot \mathrm{cm}^{-3}\right)\end{array}$} & \multicolumn{3}{|c|}{$\begin{array}{c}\text { Particles size } \\
\text { distribution (\%) }\end{array}$} & \multirow{2}{*}{$\begin{array}{c}\text { Cations } \\
\text { equilib- } \\
\text { rium } \\
(\mathrm{Ca} / \mathrm{Mg} / \mathrm{K}) \\
(76 / 18 / 6)\end{array}$} \\
\hline & & OC $(\%)$ & $\mathrm{N}(\%)$ & $\begin{array}{c}\mathrm{P} \\
\left(\mathrm{mg} \cdot \mathrm{kg}^{-1}\right)\end{array}$ & $\mathrm{Ca}^{2+}$ & $\mathrm{Mg}^{2+}$ & $\mathrm{K}^{+}$ & $\begin{array}{c}\mathrm{Na}^{+} \\
\left(\mathrm{cmol}^{\circ} \mathrm{kg}^{-1}\right)\end{array}$ & $\mathrm{S}$ & & $\mathrm{Al}^{3+}$ & $\mathrm{m}(\%)$ & $\mathrm{pH}$ & & clay $\begin{array}{c}\text { Fine } \\
\text { silt }\end{array}$ & $\begin{array}{l}\text { Coarse } \\
\text { silt }\end{array}$ & sand & \\
\hline $\begin{array}{l}\text { Not } \\
\text { tilled }\end{array}$ & NT & $6.5 \pm 1.4$ & $4.51 \pm 1.1$ & $7.0 \pm 1.0$ & 1.68 & 0.94 & 0.76 & 0.03 & $\begin{array}{c}3.58 \pm \\
0.4\end{array}$ & $\begin{array}{c}22.0 \pm \\
3.1\end{array}$ & 0.31 & $\begin{array}{c}5.9 \pm \\
1.7\end{array}$ & $\begin{array}{c}4.62 \pm \\
0.2\end{array}$ & 0.69 & 29.052 .0 & 17.0 & 2.0 & $78 / 17 / 5$ \\
\hline \multirow{2}{*}{ Tilled } & $\mathrm{T} 1$ & $5.7 \pm 0.2$ & $4.15 \pm 0.6$ & $22.2 \pm 1.6$ & 1.76 & 1.05 & 0.75 & 0.02 & $\begin{array}{c}3.58 \pm \\
0.7\end{array}$ & $\begin{array}{r}18.0 \\
\pm 1.9\end{array}$ & 0.23 & $\begin{array}{c}7.0 \pm \\
1.0\end{array}$ & $\begin{array}{c}4.42 \pm \\
0.5\end{array}$ & 0.93 & 36.047 .0 & 13.0 & 4.0 & $54 / 39 / 7$ \\
\hline & $\mathrm{T} 2$ & $4.8 \pm 0.5$ & $2.95 \pm 0.7$ & $11.7 \pm 1.9$ & 3.08 & 1.48 & 1.03 & 0.02 & $\begin{array}{c}4.84 \pm \\
1.1\end{array}$ & $\begin{array}{l}20.9 \\
\pm 2.7\end{array}$ & 0.19 & $\begin{array}{c}5.5 \pm \\
0.4\end{array}$ & $\begin{array}{c}4.53 \pm \\
0.2\end{array}$ & 1.09 & 31.053 .0 & 13.0 & 3.0 & $73 / 20 / 7$ \\
\hline \multirow{2}{*}{ Burn } & B1 & $0.8 \pm 0.0$ & $0.95 \pm 0.0$ & $18.7 \pm 0.0$ & 6.27 & 4.43 & 3.98 & 0.03 & $\begin{array}{c}5.74 \pm \\
0.0\end{array}$ & $\begin{array}{l}10.2 \\
\pm 0.0\end{array}$ & 0.00 & $\begin{array}{c}0.0 \pm \\
0.0\end{array}$ & $\begin{array}{c}6.54 \pm \\
0.0\end{array}$ & 0.77 & 20.034 .0 & 34.0 & 12.0 & $58 / 25 / 17$ \\
\hline & B2 & $1.5 \pm 0.0$ & $1.96 \pm 0.0$ & $43.6 \pm 0.0$ & 5.87 & 3.05 & .3 .6 & 0.06 & $\begin{array}{c}3.94 \pm \\
0.0\end{array}$ & $\begin{array}{c}11.4 \pm \\
0.0\end{array}$ & 0.01 & $\begin{array}{c}0.1 \pm \\
0.0\end{array}$ & $\begin{array}{c}6.18 \pm \\
0.0\end{array}$ & 0.79 & 14.049 .0 & 29.0 & 2.0 & $41 / \mathbf{5 1} / 8$ \\
\hline $\begin{array}{l}\text { Fal- } \\
\text { low }\end{array}$ & F2 & $5.5 \pm 0.3$ & $1.87 \pm 0.3$ & $15.9 \pm 0.8$ & 1.67 & 1.06 & 1.01 & 0.01 & $\begin{array}{c}4.39 \pm \\
0.0\end{array}$ & $\begin{array}{l}21.6 \\
\pm 3.2\end{array}$ & 0.31 & $\begin{array}{c}5.7 \pm \\
1.1\end{array}$ & $\begin{array}{c}4.47 \pm \\
0.00\end{array}$ & 1.09 & 31.050 .0 & 16.0 & 3.0 & $63 / 33 / 4$ \\
\hline
\end{tabular}

$$
M W D=\sum_{i=1}^{n} x_{i} w_{i}
$$

where $n$ is the number of aggregate size ranges above $0.5 \mathrm{~mm}, w_{i}$ is the weight of aggregates in a size class of average diameter $x i$, and $w_{0}$ is the total weight of aggregates placed on $5 \mathrm{~mm}$ sieve for analysis.

The mean values of the soil chemical and physical properties in each series of plots under the same land use and management system were obtained using M.S. EXCEL software.

\section{RESULTS}

\subsection{Soil Chemical Properties}

\subsubsection{Organic Carbon (OC), Total Nitrogen (N) and Available Phosphorous (P)}

The soil OC content is high in the study plots and varies from $4.8 \%$ to $6.5 \%$, except in $\mathrm{B} 1(0.8 \%)$ and $\mathrm{B} 2$ $(1.5 \%)$ (Table 1). It decreeses slightly from NT $(6.5 \%)$ to $\mathrm{T} 1(5.7 \%)$ and $\mathrm{T} 2(4.8 \%)$, and abruptly in B1 $(0.8 \%)$ and B2 (1.5\%). Inversely, it increases in F1 (6.5\%) and F2 (5.5\%) compared to $\mathrm{T} 1$ and $\mathrm{T} 2$. The total $\mathrm{N}$ content follows the same trend like the soil OC content and varies from $0.95 \%$ to $5.04 \%$. It thus decreases slightly from NT $(4.51 \%)$ to T1 $(4.15 \%$ ) and T2 (2.96\%), and abruptly in B1 (0.95\%o) and B2 (1.96\%), and increases significantly in F1 (5.04\%), even remains low in F2 (1.87\%). The available $\mathrm{P}$ content varies from 7.0 to $43.6 \mathrm{mg} \cdot \mathrm{kg}^{-1}$ in the study plots. Its lowest value is in NT $\left(7.0 \mathrm{mg} \cdot \mathrm{kg}^{-1}\right)$. It increases in $\mathrm{T} 1\left(22.2 \mathrm{mg} \cdot \mathrm{kg}^{-1}\right)$, T2 $\left(11.7 \mathrm{mg} \cdot \mathrm{kg}^{-1}\right), \mathrm{B} 1$ (18.7 $\left.\mathrm{mg} \cdot \mathrm{kg}^{-1}\right)$ and $\mathrm{B} 2\left(43.6 \mathrm{mg} \cdot \mathrm{kg}^{-1}\right)$, but decreases in $\mathrm{F} 1\left(10.8 \mathrm{mg} \cdot \mathrm{kg}^{-1}\right)$ and $\mathrm{F} 2\left(15.9 \mathrm{mg} \cdot \mathrm{kg}^{-1}\right)$ relative to $\mathrm{T} 1$ and $\mathrm{T} 2$.

\subsubsection{Cations Exchange Capacity (CEC), Exchangeable Cations and Acidity}

The CEC content is relatively high in the study plots and varies from 10.2 to $22.0 \mathrm{cmol} \cdot \mathrm{kg}^{-1}$ (Table 1). The highest value is in NT $\left(22.0 \mathrm{cmol} \cdot \mathrm{kg}^{-1}\right)$. It decreases slightly in T1 $\left(18.0 \mathrm{cmol} \cdot \mathrm{kg}^{-1}\right)$ and T2 $\left(20.7 \mathrm{cmol} \cdot \mathrm{kg}^{-1}\right)$, and severely in B1 $\left(10.2 \mathrm{cmol} \cdot \mathrm{kg}^{-1}\right)$ and B2 $\left(11.4 \mathrm{cmol} \cdot \mathrm{kg}^{-1}\right)$, but increases slightly in F1 $\left(20.6 \mathrm{cmol} \cdot \mathrm{kg}^{-1}\right)$ and $\mathrm{F} 2$ $\left(21.6 \mathrm{cmol} \cdot \mathrm{kg}^{-1}\right)$ with respects to T1 and T2. The sum of exchangeable cations (S) is very low in the study soils (3.6 to $\left.5.7 \mathrm{cmol} \cdot \mathrm{kg}^{-1}\right)$. It increases slightly from NT (3.6 $\left.\mathrm{cmol} \cdot \mathrm{kg}^{-1}\right)$ to T2 $\left(4.9 \mathrm{cmol} \cdot \mathrm{kg}^{-1}\right), \mathrm{B} 1\left(5.7 \mathrm{cmol} \cdot \mathrm{kg}^{-1}\right), \mathrm{B} 2$ (3.9 $\left.\mathrm{cmol} \cdot \mathrm{kg}^{-1}\right)$, F1 $\left(5.1 \mathrm{cmol} \cdot \mathrm{kg}^{-1}\right)$ and $\mathrm{F} 2 \quad(4.3$ $\left.\mathrm{cmol} \cdot \mathrm{kg}^{-1}\right)$, and remain unchanged in T1 $\left(3.6 \mathrm{cmol} \cdot \mathrm{kg}^{-1}\right)$. It highest content is in B1. The most abundant exchangeable cation is $\mathrm{Ca}^{2+}\left(1.60\right.$ to $\left.3.92 \mathrm{cmol} \cdot \mathrm{kg}^{-1}\right)$, followed by $\mathrm{Mg}^{2+}$ ( 0.61 to $\left.2.00 \mathrm{cmol} \cdot \mathrm{kg}^{-1}\right), \mathrm{K}^{+}(0.15$ to 0.99 cmol $\left.\cdot \mathrm{kg}^{-1}\right)$ and $\mathrm{Na}^{+}\left(0.03\right.$ to $\left.0.09 \mathrm{cmol} \cdot \mathrm{kg}^{-1}\right)$. The cations equilibrium is close to the optimal equilibrium $(76 / 18 / 6)$ in NT (78/17/5), T2 (73/20/7) and F1 (78/17/5), and highly unbalanced in T1 (54/39/7), B1 (58/25/17), B2 $(41 / 51 / 8)$ and F2 (63/33/4) with respect to a Ca deficiency. The exchangeable $\mathrm{Al}^{3+}$ content varies from 0.00 to $0.28 \mathrm{cmol} \cdot \mathrm{kg}^{-1}$. Consequently, the aluminium toxicity is relatively low (m: $0.0 \%$ to $7.0 \%$ ). Nevertheless, the study soils are strongly acids ( $\mathrm{pH} 4.42$ to 4.64 ), except for B1 and B2 with weak acid soils (pH 6.54 and 6.18 respectively). This acidity increases slightly from NT ( $\mathrm{pH} 4.62$ ) to $\mathrm{T} 1$ ( $\mathrm{pH} 4.42)$ and $\mathrm{T} 2(\mathrm{pH} \mathrm{4.53)}$, but decreases abruptly in $\mathrm{B} 1(\mathrm{pH} 6.54)$ and $\mathrm{B} 2(\mathrm{pH} \mathrm{6.18)}$ ) and slightly in $\mathrm{F} 1$ (pH 4.64) and F2 (pH 4.47) relative to T1 and $\mathrm{T} 2$. 
Table 2. Soil aggregates stability in the study plots (WSA: water stable aggregates; GMD: geometric mean diameter; MWD: mean weight diameter).

\begin{tabular}{|c|c|c|c|c|c|c|c|c|c|c|}
\hline \multirow{2}{*}{ Study plots } & \multirow[t]{2}{*}{ Test } & \multicolumn{3}{|c|}{ Slow wetting test } & \multicolumn{3}{|c|}{ Fast wetting test } & \multicolumn{3}{|c|}{ Stirring after wetting test } \\
\hline & & WSA $(\%)$ & $G M D(\mathrm{~mm})$ & $M W D(\mathrm{~mm})$ & WSA $(\%)$ & $G M D(\mathrm{~mm})$ & $M W D(\mathrm{~mm})$ & WSA $(\%)$ & $G M D(\mathrm{~mm})$ & $M W D(\mathrm{~mm})$ \\
\hline Not tilled & NT & 53.8 & 1.76 & 2.69 & 38.9 & 1.55 & 1.95 & 38.2 & 1.47 & 1.91 \\
\hline Tilled & $\mathrm{T} 1$ & 48.4 & 1.62 & 2.42 & 37.9 & 1.44 & 1.90 & 34.5 & 1.26 & 1.72 \\
\hline \multirow{2}{*}{ Burn } & B1 & 53.3 & 1.70 & 2.66 & 53.3 & 1.69 & 2.67 & 46.7 & 1.55 & 2.34 \\
\hline & $\mathrm{B} 2$ & 57.0 & 1.72 & 2.85 & 51.4 & 1.70 & 2.57 & 52.2 & 1.64 & 2.61 \\
\hline \multirow{2}{*}{ Fallow } & $\mathrm{F} 1$ & 40.1 & 1.55 & 2.00 & 27.5 & 1.28 & 1.38 & 48.2 & 1.67 & 2.41 \\
\hline & $\mathrm{F} 2$ & 48.8 & 1.63 & 2.44 & 42.5 & 1.53 & 2.13 & 29.6 & 1.28 & 1.48 \\
\hline
\end{tabular}

\subsection{Soil Physical Properties}

\subsubsection{Bulk Density (da) and Particle Size Distribution}

The bulk density (da) varies from 0.69 to $1.14 \mathrm{~g} \cdot \mathrm{cm}^{-3}$. The lowest value is in NT $\left(0.69 \mathrm{~g} \cdot \mathrm{cm}^{-3}\right)$. It increases significantly in T1 $\left(0.93 \mathrm{~g} \cdot \mathrm{cm}^{-3}\right)$, T2 $\left(1.09 \mathrm{~g} \cdot \mathrm{cm}^{-3}\right), \mathrm{F} 1$ $\left(1.14 \mathrm{~g} \cdot \mathrm{cm}^{-3}\right)$ and $\mathrm{F} 2\left(1.09 \mathrm{~g} \cdot \mathrm{cm}^{-3}\right)$, and lesser in B1 $\left(0.77 \mathrm{~g} \cdot \mathrm{cm}^{-3}\right)$ and B2 $\left(0.79 \mathrm{~g} \cdot \mathrm{cm}^{-3}\right)$. The silt (60 to $\left.78 \%\right)$ and clay (14 to $36 \%$ ) fractions are dominant. The clay fraction increases in T1 (36\%) and T2 $(31 \%)$, and decreases in B1 $(20 \%)$ and B2 (14\%) relative to NT $(29 \%)$. It also decreases in F1 (25\%) and F2 (31\%) compared to $\mathrm{T} 1$ and T2. The highest fine silt content is in NT (53\%). It decreases in T1 (47\%), B1 (34\%), B2 (49\%), F1 (45\%) and F2 (50\%) and remains unchanged in T2 (53\%). The coarse silt abundance also decreases from NT (17\%) to $\mathrm{T} 1(13 \%)$ and T2 (13\%), but increases in B1 (34\%) and B2 (29\%). It also increases in F1 (28\%) and F2 (16\%) compared to $\mathrm{T} 1$ and $\mathrm{T} 2$. The sand fraction is the less abundant $(2 \%$ to $12 \%)$ with the highest value in B1 $(12 \%)$.

\subsubsection{Aggregate Stability}

The soil aggregate stability parameters are displayed in Table $2(29.4 \%, 12.0 \%$ and $15.8 \%)$ and the highest in B2 (57.0\%, 51.4\% and 52.2\%), respectively after the slow wetting, the fast wetting and the stirring after pre-wetting tests.

The geometric mean diameter $(G M D)$ of the soil macro-aggregates decreases progressively after the slow wetting $(1.30-1.76 \mathrm{~mm})$, the fast wetting $(1.48-1.70$ $\mathrm{mm})$ and the stirring after pre-wetting $(0.94-1.67 \mathrm{~mm})$ tests. It decreases from NT $(1.47-1.76 \mathrm{~mm})$ to $\mathrm{T} 1(1.26$ $1.62 \mathrm{~mm}), \mathrm{T} 2(0.94-1.30 \mathrm{~mm}), \mathrm{B} 1(1.55-1.70 \mathrm{~mm}), \mathrm{B} 2$ $(1.64-1.72 \mathrm{~mm}), \mathrm{F} 1(1.28-1.67 \mathrm{~mm})$ and F2 (1.28 $1.63 \mathrm{~mm}$ ) whatever the test. The lowest GMD values are in T2 $(1.30 \mathrm{~mm}, 1.18 \mathrm{~mm}$ and $0.94 \mathrm{~mm}$, respectively after the slow wetting, the fast wetting and the stirring after pre-wetting tests).

The mean weight diameter (MWD) of the soil macroaggregates also decreases severely after the slow wetting $(1.47-2.69 \mathrm{~mm})$, the fast wetting $(0.60-2.67 \mathrm{~mm})$ and the stirring after pre-wetting $(0.79-2.61 \mathrm{~mm})$ tests. It always decreases from NT $(1.91-2.69 \mathrm{~mm})$ to T1 $(1.72$ - $2.42 \mathrm{~mm}), \mathrm{T} 2(0.60-1.47 \mathrm{~mm}), \mathrm{F} 1(1.38-2.41 \mathrm{~mm})$ and F2 (1.48 - $2.44 \mathrm{~mm})$, but increases in B1 (2.34 - 2.67 $\mathrm{mm})$ and B2 (2.57 - $2.85 \mathrm{~mm})$. The lowest $M W D$ values of these soil macro-aggregates remain in T2 $(1.47 \mathrm{~mm}$, $0.60 \mathrm{~mm}$ and $0.79 \mathrm{~mm}$ after the slow wetting, the fast wetting and the stirring after pre-wetting tests respectively)

The water stable aggregates (WSA) abundance in the study soils remains relatively high after the slow wetting test, and vary from $29.4 \%$ to $57.0 \%$. It decreases significantly after the fast wetting $(12.0 \%$ to $53.3 \%)$ and the stirring after pre-wetting ( $15.8 \%$ to $52.2 \%)$ tests regardless of the land use and management systems. It decreases in T1 (34.5\% - 48.4\%), T2 (12.0\% - 29.4\%), F1 $(27.5 \%-48.2 \%)$ and F2 (29.6\% - 48.8\%); but increases slightly in B1 $(46.7 \%-53.3 \%)$ and B2 (51.4\% - 57.0\%) compared to NT $(38.2 \%-53.8 \%)$. The lowest WSA abundance is in $\mathrm{T} 2$

\section{DISCUSSION}

Variations in most of the soil chemical and physical properties are the key for understanding the impact of land use and management systems on soil quality.

\subsection{Changes in Soil Chemical Properties}

In the Andosols from Mount Bambouto, the tillage management system results in a significant reduction of the soil organic matter expressed by the soil OC $(6.5 \%$ to $4.8 \%)$ and the total $\mathrm{N}(4.51 \%$ to $2.96 \%$ ) contents, giving a reduction ratio of $26.1 \%$ and $34.4 \%$ respectively . Similar reduction has been reported $[9,10]$ with the soil OC losses ranging from $15 \%$ to $40 \%$ within 2 - 12 years of tillage $[11,12]$. Such reduction is commonly attributed to the microbial oxidation of the organic compounds previously protected in the soil aggregates which where destroyed by cultivation $[13,14]$. The burning management system also reduces severely the soil organic matter content by calcinations (OC: $6.5 \%$ to $0.8 \%, \mathrm{~N}: 4.51 \%$ to $0.95 \%$ ) giving a reduction ratio of $87.7 \%$ and $78.9 \%$ respectively. Generally, reduction in the soil organic 
matter content influences negatively the fertility of Andosols, since it is known to play a central role in the exchangeable cations retention [15]. This reduction could also increase the soil erodibility, causing an offsite transport of the soil nutrients and the subsequent soil fertility decline. Conversely, the fallow management system improves the soil organic matter content relative to the tillage management system (OC: $4.8 \%$ to $6.5 \%, \mathrm{~N}$ : $2.96 \%$ to $5.04 \%$ ) with an increasing ratio of $26.1 \%$ and $41.3 \%$ respectively. This increase in the soil organic matter content with fallow may be consistent with additional supply of the organic residues which act as compost with time [16]. These particulate organic matters are protected physically in soil aggregates [17].

In the Andosols from Mount Bambouto, the tillage and burning management systems also lead to a net loss of the CEC content ( 22.0 to 18.0 and $10.2 \mathrm{cmol} \cdot \mathrm{kg}^{-1}$ ) with a reduction ratio of $18.2 \%$ and $53.6 \%$ respectively, giving rise to the soil fertility decline [18], whereas the fallow management system restores it relative to the tillage management system (18.0 to $\left.21.6 \mathrm{cmol} \cdot \mathrm{kg}^{-1}\right)$ with an increasing ratio of $16.7 \%$. Inversely, the above three land use and management systems are marked by a slight increase of the sum of the exchangeable cations relative to the natural cover (3.6 to $4.9 \mathrm{cmol} \cdot \mathrm{kg}^{-1}, 5.7$ and 5.1 $\mathrm{cmol} \cdot \mathrm{kg}^{-1}$ ) with and increasing ratio of $26.5 \%, 36.8 \%$ and $29.4 \%$ respectively. In the tillage management system, this may be due to an input of fertilizers during land preparation. In the fallow management system, it suggests that this unmanaged period can restore the soil nutrients exported by the harvest of the plant biomass. In the burning management system, it may be consistent with the release of the base cations during soil calcination [19] as indicated by the net increase in the soil $\mathrm{pH}$ values in B1 (6.54) and B2 (6.18). Thus, the burning management system improves the soil fertility through accumulation of the exchangeable cations. But it is well known that this improvement lasts only for a short period and that the water erosion and the subsequent soil nutrients leaching leads to soil impoverishment [19]. The soil acidity also increases in the tillage management system compared to the natural cover ( $\mathrm{pH} 4.62$ to 4.42), inducing the decrease in the agricultural productivity [20]. Even 10 years of the fallow management system practice (F2 plots) is not enough to improve this strong acidity induced by the tillage management system. Always in the Andosols from Mount Bambouto, the long-term tillage (T2 plots) and the fallow management systems have brought the cations equilibrium close to the optimal equilibrium (T2: 73/20/7, F1: 78/17/5 and F2: 63/33/4) and consequently improve Andosol fertility. Inversely, the short-term tillage (T1 plots) and the burning management systems provoke the cations imbalance (T1: 54/39/7, B1: 58/25/17 and B2: 41/51/8) with a significant $\mathrm{Ca}^{2+}$ deficiency. This $\mathrm{Ca}^{2+}$ deficiency may induce a severe antagonism between the cations during the plants nutrition.

\subsection{Changes in Soil Physical Properties}

The soil compaction (36.7\%) induced by the tillage management system and expressed by the soil bulk density increase $\left(0.69\right.$ to $\left.1.09 \mathrm{~g} \cdot \mathrm{cm}^{-3}\right)$ has significant effect on soil physical properties. It reduces infiltration and percolation of water, and thus favours the surface runoff and land degradation by soil erosion. Even after 10years of the fallow management system practice, these soils seem to have not recovered from the tillage management system induced compaction.

The water stable aggregates (WSA: $12.0 \%-53.3 \%$ and $15.8 \%-52.2 \%)$ abundance, the geometric mean diameter (GMD: $1.18-1.70 \mathrm{~mm}$ and $0.94-1.67 \mathrm{~mm}$ ) and the mean weight diameter (MWD: $0.60-2.57 \mathrm{~mm}$ and $0.79-2.61$ $\mathrm{mm}$ ) values reveal that the fast wetting and the stirring after pre-wetting tests representing moderate to violent storms highly disrupt the Andosol macro-aggregates. The slow wetting test corresponding to moderate rainfalls is least disruptive (WSA: 29.4\% - 57.0\%; GMD: 1.30 - 1.76 mm; MWD: 1.47 - $2.85 \mathrm{~mm})$. Globally, the Andosols from Mount Bambouto have low to moderate resistance to water erosion. As the land use and management system is concerned, the tillage management system lead to an important destruction of the Andosol macro-aggregates (WSA: $12.0 \%$ - 48.4\%; GMD: 0.94 - $1.62 \mathrm{~mm}$ and MWD: $0.60-2.42 \mathrm{~mm})$, whereas the burning management system regenerates them ((WSA: 46.7\% - 57.0\%; GMD: 1.55 - $1.72 \mathrm{~mm}$ and MWD: 2.34 - $2.85 \mathrm{~mm})$. The fallow management system also regenerates the Andosol macroaggregates after the tillage management system practice (WSA: 27.5\% - 48.8\%; GMD: 1.28 - $1.67 \mathrm{~mm}$ and MWD: $1.38-2.44 \mathrm{~mm})$. The destruction of the Andosol macroaggregates by the tillage management system with it subsequent increasing clay fraction $(36 \%)$ may be consistent with the mechanical breakdown of the soil aggregates by ploughing. The regeneration of the Andosol macro-aggregates with the burning management system practice may be related to $\mathrm{Al}^{3+}$ activity in the soil solution. In fact, above $\mathrm{pH} 5.5, \mathrm{Al}^{3+}$ precipitates in soil as hydroxides and can act as links between mineral particles, generating soil aggregates. Under the fallow management system, the regeneration of the Andosol macro-aggregates may be associated to the formation of the organometal and oxides-humus complexes with organic acids acting as binding agent [21]. The increase in the Andosol macro-aggregates abundance in both cases and the relatively low bulk density indicate well-structured soils with good pore connectivity. 


\section{CONCLUSIONS}

The tillage management system is a significant driver of the Andosol fertility decline. It reduces significantly the soil organic matter and the CEC content, increases soil acidity and compaction, and destroys the Andosol macro-aggregates; the chemical and physical properties that affect negatively the Andosol quality. The relative increase of the sum of the exchangeable cations and the cations equilibrium close to the optimal equilibrium after 10 years of tillage practice are not enough to restore efficiently the Andosol fertility.

The burning management system has mitigated influences on Andosols quality. The severe reduction of the soil organic matter and the CEC content, and the cations equilibrium imbalance in the burning management system affect negatively the Andosol quality. Inversely, the net increase of the sum of the exchangeable cations and the soil $\mathrm{pH}$ above 6 , and the fairly high soil macro-aggregates abundance contribute to improve significantly the Andosol quality. But this improvement lasts only for a short period because the water erosion and it subsequent nutrients leaching leads to the soil impoverishment.

The fallow management system globally improves significantly the Andosol quality. It is sustainable in term of the soil organic matter, the CEC and the sum of the exchangeable cations increase, and the soil macro-aggregates regeneration after the tillage management system practice. But, even 10 years of the fallow management system is not enough to regenerate efficiently the soil macro-aggregates and improve the soil acidity.

\section{REFERENCES}

[1] Dumanski, J. and Pieri, C. (2000) Land quality indicators: Research plan. Agriculture, Ecosystems and Environment, 81, 93-102. doi:10.1016/S0167-8809(00)00183-3

[2] Oldeman, L.R., Hakkeling, R.T.A. and Sombroek, W.G. (1990) World map of human-induced soil degradation. ISRIC: Wageningen, UNEP: Nairobi.

[3] Smaling, E.M.A., Fresco, L.O. and de Jager, A. (1996) Classifying monitoring and improving soil nutrient stocks and flows in African agriculture. Ambio, 25, 492496.

[4] Harris, F.M.A. (1998) Farm-level assessment of the nutrient balance in northern Nigeria. Agriculture, Ecosystems and Environment, 71, 201-214. doi:10.1016/S0167-8809(98)00141-8

[5] Tematio, P., Kengni, L., Bitom, D., Hodson, M., Fopoussi, J.C., Leumbe, O., Mpakam, H.G. and Tsozué, D. (2004) Soils and their distribution on Bambouto volcanic mountain, West Cameroon highland, central Africa. Journal of African Earth Sciences, 39, 447-457. doi:10.1016/j.jafrearsci.2004.07.020

[6] Tematio, P. and Olson, K.R. (1997) Impacts of industrialized agriculture on land in Bafou, Cameroon. Journal of Soil and Water Conservation, 52, 404-405.
[7] Blake, G.R. (1982) Bulk density. Soil science methods of soil analysis. American Society of Agronomy and Crop Science Society of America, Madison, 374-390.

[8] Le Bissonnais, Y. (1996) Aggregate stability and assessment of soil crustability and erodibility: I. Theory and methodology. European Journal of Soil Science, 47, 425437. doi:10.1111/j.1365-2389.1996.tb01843.x

[9] Mbagwu, J.S.C. and Piccolo, A. (1998) Water-dispersible clay in aggregates of forest and cultivated soils in southern Nigeria in relation to organic matter constituents. In: Bergström, L. and Kirchman, H., Eds., Carbon and $\mathrm{Nu}$ trient Dynamics in Natural and Agricultural Ecosystems, CAB International, Wallingford, 71-83.

[10] Spaccini, R., Piccolo, A., Haberhauer, G. and Gerzabek, M. (2000) Transformation of organic matter from maize residues into labile and humic fractions of three European soils as revealed by $13 \mathrm{C}$ distribution and CPMASNMR spectra. European Journal of Soil Science, 51, 583-594.

[11] Davidson, E.A. and Ackerman, I.L. (1993) Changes in soil carbon inventories following cultivation of previously untilled soils. Biogeochemistry, 20, 161-193. doi:10.1007/BF00000786

[12] Evrendilek, F., Celik, I. and Kilic, S. (2004) Changes in soil organic carbon and other physical soil properties along adjacent Mediterranean forest, grassland, and cropland ecosystems in Turkey. Journal of Arid Environments, 59, 743-752.

doi:10.1016/i.jaridenv.2004.03.002

[13] Cambardella, C.A. and Elliot, E.T. (1993) Carbon and nitrogen distributions in aggregates from cultivated and native grassland soils. Soil Science Society of America Journal, 57, 1071-1076. doi:10.2136/sssaj1993.03615995005700040032x

[14] Piccolo, A. (1996) Humus and soil conservation. In: Piccolo, A., Ed., Humic Substances in Terrestrial Ecosystems, Elsevier, Amsterdam, 225-264. doi:10.1016/B978-044481516-3/50006-2

[15] Shoji, S., Nanzyo, M. and Dahlgren, R.A. (1993) Volcanic ash soil: genesis, properties and utilization. Developments in Soil Science 21, Elsevier Science Publisher, Amsterdam, 287.

[16] Feller, C., Cnoparts, L. and Daneetti, F. (1987) Effect of different millet straw addition on the low land composition of organic matter in two tropical soils in Senegal. Pedologie, 23, 237-252.

[17] Six, J., Elliott, E.T. and Paustian, K. (1999) Aggregate and soil organic matter dynamics under conventional and no-tillage systems. Soil Science Society of America Journal, 63, 1350-1358. doi:10.2136/sssaj1999.6351350x

[18] Nobel, P.S. (1989) A nutrient index quantifying productivity of agaves and cacti. Journal of Applied Ecology, 26, 635-645. doi: $10.2307 / 2404088$

[19] Sommer, R., Vlek, P.L.G., de Abreu Sá, D., Vielhauer, K., de Fátima Rodrigues Coelho, R. and Fölster, H. (2004) Nutrient balance of shifting cultivation by burning or mulching in the Eastern Amazon: Evidence for subsoil nutrient accumulation. Nutrient Cycling in Agroecosystems, 68, 257-271. doi:10.1023/B:FRES.0000019470.93637.54 
[20] Moody, P.W. and Aitken, R.L. (1997) Soil acidification under some tropical systems: 1. Rates of acidification and contributing factors. Australian Journal of Soil Research, 35, 163-173. doi:10.1071/S96069
[21] Tate, K.R. and Theng, B.K.G. (1980) Organic matter and its interactions with inorganic soil constituents. Soils with Variable Charge, Soil Bureau Department of Scientific and Industrial Research, New Zealand, 225-244. 